MALACOLOGIA, 2009, 51(1): 13-28

\title{
BENTHOCTOPUS RIGBYAE, N. SP., A NEW SPECIES OF CEPHALOPOD (OCTOPODA; INCIRRATA) FROM NEAR THE ANTARCTIC PENINSULA
}

\author{
Michael Vecchione ${ }^{1 *}$, Louise Allcock ${ }^{2,5}$, Uwe Piatkowski ${ }^{3} \&$ Jan Strugnell ${ }^{2,4}$
}

\begin{abstract}
Among the many octopods collected during recent Antarctic trawling surveys were 93 specimens of an undescribed octopod with biserial suckers. Although most similar in appearance to the sub-Antarctic Benthoctopus levis (Hoyle 1885), these octopods differed in several morphological characters, including arm length, web depth, and details of the hectocotylus. Furthermore, molecular evidence supports the separation of the present material from known species. We therefore describe a new species named Benthoctopus rigbyae. These octopods attain mantle lengths of at least $105 \mathrm{~mm}$ (400 mm total length), and they are common at depths of 250-600 m throughout the South Shetland Island chain off the Antarctic Peninsula. We present some information on the biology of this species.

Keywords: deep-sea, Southern Ocean, Octopodidae, Antarctica.
\end{abstract}

\section{INTRODUCTION}

Incirrate octopods are common members of the Antarctic marine benthos (Dell, 1972; Allcock et al., 2001). Most of the octopods collected in Antarctic samples belong to genera with uniserial suckers, such as Pareledone, Megaleledone, and their relatives (e.g., Allcock, 2005; Daly \& Rodhouse, 1994; Kuehl, 1988; Kubodera \& Okutani, 1994; Lu \& Stranks, 1994; Taki, 1961). During recent trawling cruises in the vicinity of the Antarctic Peninsula (Piatkowski et al., 1998, 2003; Barratt \& Jorgensen, 2008), we collected 93 specimens of an octopod possessing biserial suckers, but lacking an ink sac. These octopods, which came from depths of about $200-600 \mathrm{~m}$, are similar to Benthoctopus levis (Hoyle, 1885). The type locality of $B$. levis is at a depth of about $140 \mathrm{~m}$, near Heard Island, a sub-Antarctic Island in the Indian Ocean. The peninsula specimens differ from $B$. levis in relative arm length, web depth, and hectocotylus details. We therefore consider the peninsula specimens to be members of a newly discovered species of Benthoctopus, which we here name $\boldsymbol{B}$. rigbyae.

\section{MATERIALS AND METHODS}

R/V Polarstern's cruises ANT XIV/2 (November-December 1996), ANT XIX/3 (JanuaryFebruary 2002), and ANT XXIII/8 (December 2006-January 2007) focused on the South Shetland Islands northwest of the Antarctic Peninsula. One research component of each cruise was a fisheries survey using commercialsized bottom trawls (Piatkowski et al., 1998, 2003). Sampling was conducted on ANT $\mathrm{XIV} / 2$ at 40 stations around Elephant Island based on a stratified-random survey design in depths of 100-500 m. Two transects of stations northwest of King George Island at depths of 400,600 , and $800 \mathrm{~m}$ were also sampled with the same gear. A similar survey during ANT $\mathrm{XIX} / 3$ trawled at 49 stations around Elephant Island, 21 stations from 100-500 $\mathrm{m}$ depth in the southern South Shetlands, and five stations on the shelf north of Joinville Island. ANT XXIII/8 sampled 51 bottom-trawl stations around Elephant Island and another 38 stations across the Bransfield Straits close to the Peninsula, around Joinville Island and in the western Weddell Sea. Additionally, 23 samples were

${ }^{1}$ National Marine Fisheries Service, Systematics Laboratory, National Museum of Natural History, Washington, DC 20560, U.S.A.

${ }^{2}$ Ecology and Evolutionary Biology, School of Biological Sciences, Queen's University Belfast, 97 Lisburn Road, Belfast BT9 7BL, United Kingdom

${ }^{3}$ Institute for Marine Research, University Kiel, Dusternbrooker Weg 20, D-24105, Kiel, Germany

${ }^{4}$ British Antarctic Survey, Natural Environmental Research Council, High Cross, Madingley Rd., Cambridge, CB3 0ET, United Kingdom

${ }^{5}$ Current address: The Martin Ryan Institute for Marine Science, National University of Ireland, Galway, University Rd., Galway, Ireland

*Corresponding author: vecchiom@si.edu 
TABLE 1. Criteria used for male and female maturity stages.

\begin{tabular}{|c|c|c|}
\hline & Male & Female \\
\hline Stage 1 & Sex undeterminable & Sex undeterminable \\
\hline Stage 2 & $\begin{array}{l}\text { Testes developing or developed, but no } \\
\text { spermatophores developing }\end{array}$ & Ovary small and round, eggs tiny \\
\hline Stage 3 & $\begin{array}{l}\text { Spermatophores developing but none are } \\
\text { mature }\end{array}$ & Eggs begin to enlarge \\
\hline Stage 4 & $\begin{array}{l}\text { Few mature spermatophores present in } \\
\text { Needham's sac }\end{array}$ & $\begin{array}{l}\text { Ovaries swollen and oviducal glands en- } \\
\text { larged }\end{array}$ \\
\hline Stage 5 & $\begin{array}{l}\text { Four or more mature spermatophores present } \\
\text { in Needham's sac and terminal organ }\end{array}$ & $\begin{array}{l}\text { Ovaries completely distended with many } \\
\text { mature eggs }\end{array}$ \\
\hline Stage 6 & Needham's sac swollen but empty & $\begin{array}{l}\text { Ovaries swollen but empty, oviducal glands } \\
\text { enlarged }\end{array}$ \\
\hline
\end{tabular}

collected with an Agassiz beam-trawl on ANT $\mathrm{XIV} / 2$, nine with a smaller Agassiz trawl on ANT $\mathrm{XIX/3}$, and 15 on ANT XXIII/8, at various depths between 100-5,200 m. Details of all stations, including those that did not yield Benthoctopus, can be found in the cruise reports (Arntz \& Brey, 1997; Kattner et al., 1998; Barratt \& Jorgensen, 2008). Details of stations yielding Benthoctopus are provided in Figure 8.

All cephalopods were retrieved from all samples. Station locations and distribution of these cephalopods are presented by Piatkowski et al. (1998, 2003) and Barratt \& Jorgensen (2008). Dorsal mantle length (ML) and total length were measured and sex and maturity stage determined according to set criteria (Table 1) for all specimens.

Under material examined, we list stage 1 as juvenile, stages 2-3 as immature, stages 4-5 as mature, and stage 6 as spent. Additionally for 15 males and 12 females representing the full range of size and maturity encountered, the following measurements and counts (following Roper \& Voss, 1983) were recorded prior to fixation: measurements (Tables 2, 3) - ventral mantle length, mantle width, head width, eye length, width of pallial aperture, full funnel length, free funnel length, web formula, depth of deepest web segment, arm width, length of each arm, sucker diameter; counts (Table 4 ) - numbers of suckers on left (males and females) and right (males only) ventrolateral arms, number of suckers on the longest arm, number of inner and outer gill lamellae. The lengths of the calamus and ligula were recorded for males and, for six mature males, the length and width of a mature spermatophore as well. For six mature females, the length and width of the largest ovarian egg was measured.
Some specimens were dissected to examine internal anatomy prior to fixation. Dissections emphasized male and female reproductive anatomy and comparative anatomy of digestive tracts. Eleven females and 24 males were weighed to examine the relationship between length and weight. Stomach contents were determined for a few specimens, selected arbitrarily.

\section{Molecular Analyses}

Tissue samples were taken from two Benthoctopus specimens from the Antarctic Peninsula (NMSZ 2002037.032 and USNM 1021054) and preserved in $70 \%$ ethanol. Tissue samples were also preserved in $70 \%$ ethanol from a specimen of Benthoctopus sp. captured in the eastern Weddell Sea and from two specimens of Benthoctopus levis captured around Heard Island. We also obtained a beak taken from a Benthoctopus specimen presumed to be $B$. thielei Robson, 1932, captured off Kerguelen Island, and extracted DNA from this. Although DNA has previously been extracted from beach-washed Spirula shells (Strugnell et al., 2006), we believe that this is the first published report of DNA from a cephalopod beak.

The DNA extraction protocol followed that given in Allcock et al. (2006). Primers for three mitochondrial genes (12S rDNA, 16S rDNA, $\mathrm{COI}$ ) were taken from the literature (Simon et al., 1990, 1991; Folmer et al., 1994), with the 12S rDNA and COI primers modified slightly to match cephalopod sequences on GenBank. Polymerase chain reactions (PCR) were carried out in $25 \mathrm{ml}$ volumes. Thermal cycling conditions consisted of a denaturation step at $94^{\circ} \mathrm{C}$ for $2 \mathrm{~min}$, followed by 35 cycles of $94^{\circ} \mathrm{C}$ 
TABLE 2. Measurements (mm) of type specimens of Benthoctopus rigbyae $\mathrm{n}$. $\mathrm{sp}$. as archived at NMNH. Dorsal mantle length (prior to fixation) was measured on freshly collected specimens onboard ship.

\begin{tabular}{|c|c|c|c|}
\hline \multirow[b]{2}{*}{ Sex } & \multirow{2}{*}{$\begin{array}{c}\text { Holotype } \\
\text { male }\end{array}$} & \multicolumn{2}{|c|}{ Paratypes } \\
\hline & & female & female \\
\hline Total length & 229 & 259 & 243 \\
\hline Dorsal mantle length (prior to fixation) & 64 & 55 & 52 \\
\hline Dorsal mantle length (preserved) & 49 & 47 & 42 \\
\hline Ventral mantle length & 43 & 46 & 38 \\
\hline Mantle width & 37 & 45 & 33 \\
\hline Head width & 23 & 28 & 25 \\
\hline Eye diameter & 9 & 8 & 6 \\
\hline Pallial aperture width & 25 & 29 & 26 \\
\hline Full funnel length & 16 & 17 & 14 \\
\hline Free funnel length & 12 & 13 & 10 \\
\hline Deepest web segment depth & 26 & 47 & 30 \\
\hline Arm width (longest arm) & 5 & 4 & 5 \\
\hline Left dorsal arm length & 176 & 200 & 168 \\
\hline Left dorsolateral arm length & 175 & 202 & 169 \\
\hline Left ventrolateral arm length & 147 & 201 & 180 \\
\hline Left ventral arm length & 164 & 196 & 166 \\
\hline Right dorsal arm length & 179 & 200 & 165 \\
\hline Right dorsolateral arm length & 156 & 182 & 179 \\
\hline Right ventrolateral arm length & 127 & 189 & 167 \\
\hline Right ventral arm length & 166 & 183 & 172 \\
\hline Diameter of largest sucker & 5 & 6 & 5 \\
\hline Calamus length & 6 & & \\
\hline Ligula length & 17 & & \\
\hline Web depth, segment $A$ & 21 & 47 & 29 \\
\hline Web depth, segment B & 26 & 33 & 28 \\
\hline Web depth, segment $\mathrm{C}$ & 26 & 29 & damaged \\
\hline Web depth, segment $D$ & 25 & 29 & 30 \\
\hline Web depth, segment E & 25 & 16 & 24 \\
\hline
\end{tabular}

for $40 \mathrm{~s}, 50^{\circ} \mathrm{C}$ for $40 \mathrm{~s}$, and $72^{\circ} \mathrm{C}$ for $90 \mathrm{~s}$. A final extension step of $72^{\circ} \mathrm{C}$ for 10 min was added in each case. Annealing temperatures varied according to the primers used and are available from the authors on request. Amplified products were purified using the QiaGen PCR purification kit following the manufacturer's instructions. Purified PCR products were commercially sequenced by Macrogen Inc. in both directions using the same primers used for PCR amplification. Sequences for Enteroctopus dofleini (Wülker, 1910), Benthoctopus normani (Massy, 1907), Benthoctopus eureka (Robson, 1932), and Benthoctopus johnsoniana Allcock et al., 2006, collected from the northeastern Pacific, the Falkland Islands and the northeastern Atlantic respectively were available from previous research (Allcock et al., 2006).

DNA sequences were compiled and aligned by eye in Se-Al v2.0a11 Carbon (Rambaut 2002). The sequence data for each gene were concatenated into a single data set. Of the 1,612 characters used in the analysis, 177 (11\%) were found to be variable.

PAUP v4.0b10 (Swofford, 1998) was used to perform full heuristic searches. The phylogenetic tree is rooted using Enteroctopus dofleini, as previous phylogenetic studies using 
TABLE 3. Measurements ( $\mathrm{mm}$ ) of Benthoctopus rigbyae $\mathrm{n}$. $\mathrm{sp}$. Abbreviations: min - minimum; max maximum; s.d. - standard deviation; c.v. - coefficient of variation; $\mathrm{N}$ - number of octopods measured. Measurements were recorded at sea on freshly collected specimens. Total length and dorsal mantle length were recorded when specimens condition was adeqaute whereas other measurements were recorded on a subset of specimens when time permitted. Spermatophore and egg measurements are from the largest of each from $\mathrm{N}$ individuals rather than multiple spermatophores or eggs from a single individual.

\begin{tabular}{|c|c|c|c|c|c|c|c|}
\hline & $\min$ & $\max$ & median & mean & s.d. & c.v. & $\mathrm{N}$ \\
\hline Total length & 100 & 400 & 266 & 258 & 68 & 0.26 & 78 \\
\hline Dorsal mantle length & 18 & 105 & 60 & 60 & 18 & 0.31 & 79 \\
\hline Ventral mantle length & 28 & 85 & 60 & 58 & 15 & 0.26 & 27 \\
\hline Mantle width & 28 & 80 & 65 & 59 & 14 & 0.24 & 27 \\
\hline Head width & 21 & 49 & 40 & 39 & 7 & 0.18 & 28 \\
\hline Eye diameter & 11 & 28 & 18 & 19 & 4 & 0.20 & 28 \\
\hline Pallial aperture width & 18 & 50 & 35 & 35 & 7 & 0.20 & 27 \\
\hline Full funnel length & 15 & 36 & 27 & 27 & 6 & 0.21 & 28 \\
\hline Free funnel length & 12 & 30 & 19 & 19 & 5 & 0.26 & 28 \\
\hline Deepest web segment depth & 13 & 55 & 46 & 45 & 9 & 0.21 & 24 \\
\hline Arm width (largest arm) & 6 & 20 & 14 & 14 & 3 & 0.21 & 28 \\
\hline Left dorsal arm length & 128 & 330 & 230 & 219 & 55 & 0.25 & 23 \\
\hline Left dorsolateral arm length & 137 & 285 & 223 & 213 & 45 & 0.21 & 22 \\
\hline Left ventrolateral arm length & 127 & 320 & 223 & 216 & 50 & 0.23 & 26 \\
\hline Left ventral arm length & 124 & 300 & 223 & 217 & 49 & 0.23 & 27 \\
\hline Right dorsal arm length & 132 & 320 & 215 & 221 & 51 & 0.23 & 25 \\
\hline Right dorsolateral arm length & 130 & 320 & 225 & 220 & 52 & 0.24 & 25 \\
\hline Right ventrolateral arm length & 105 & 280 & 185 & 180 & 43 & 0.24 & 26 \\
\hline Right ventral arm length & 112 & 300 & 221 & 220 & 51 & 0.23 & 24 \\
\hline Diameter of largest sucker & 3 & 7 & 5 & 5 & 1 & 0.23 & 28 \\
\hline Calamus length & 4 & 12 & 9 & 8 & 2 & 0.25 & 15 \\
\hline Ligula length & 8 & 26 & 18 & 17 & 5 & 0.26 & 15 \\
\hline Spermatophore length & 42 & 104 & 88 & 82 & 23 & 0.29 & 6 \\
\hline Spermatophore width & 3 & 3 & 3 & 3 & 0 & - & 5 \\
\hline Length of largest egg & 13 & 24 & 18 & 17 & 4 & 0.24 & 6 \\
\hline Width of largest egg & 3 & 8 & 7 & 6 & 2 & 0.32 & 6 \\
\hline Web depth, segment $A$ & 8 & 55 & 42 & 40 & 12 & 0.31 & 15 \\
\hline Web depth, segment B & 13 & 55 & 38 & 38 & 13 & 0.33 & 15 \\
\hline Web depth, segment $\mathrm{C}$ & 9 & 55 & 44 & 41 & 13 & 0.31 & 16 \\
\hline Web depth, segment $D$ & 11 & 55 & 45 & 42 & 11 & 0.26 & 16 \\
\hline Web depth, segment E & 11 & 50 & 32 & 33 & 11 & 0.35 & 15 \\
\hline
\end{tabular}

a wide range of octopodiform species have confirmed that Enteroctopus is the sister taxon to Benthoctopus (Strugnell et al., 2005) and subsequently that Enteroctopus is a suitable outgroup to the genus Benthoctopus (Allcock et al., 2006). Starting trees were generated by neighbour joining (NJ) (Saitou \& Nei, 1987). A GTR $(\Gamma+I)$ likelihood model incorporating rate heterogeneity (four rate categories) was used.
Branch swapping was performed using TBR (tree-bisection-reconnection). Parameters were then re-estimated and finally branch swapping was performed using $\mathrm{NNI}$ (nearest-neighbour interchange). Substitution model parameter values were $A=0.34, C=0.12, G=0.15, T=$ $0.39, A \leftrightarrow C=1.48^{*} e^{8}, A \leftrightarrow G=1.53^{*} e^{9}, A \leftrightarrow T=$ $2.80^{*} \mathrm{e}^{8}, \mathrm{C} \leftrightarrow \mathrm{G}=5.55^{*} \mathrm{e}^{-11}, \mathrm{C} \leftrightarrow \mathrm{T}=2.50^{*} \mathrm{e}^{9} \mathrm{G} \leftrightarrow \mathrm{T}$ $=1.00, I=0.81, \Gamma=300$. ML bootstrap values of 


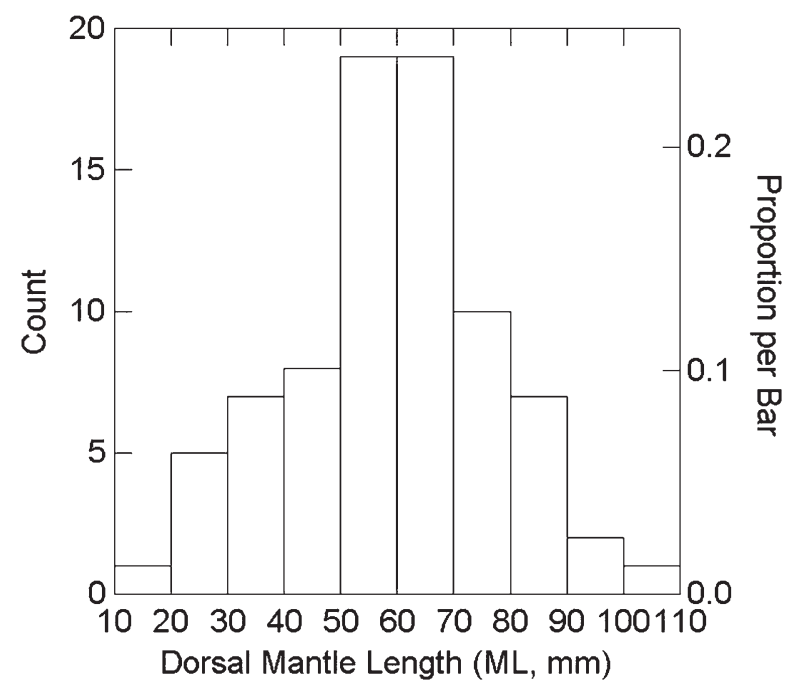

FIG. 1. Size-frequency histogram for 84 specimens of Benthoctopus rigbyae $\mathrm{n}$. $\mathrm{sp}$. examined in this study.

clade support were generated using the above parameters using 1,000 replicates.

MrBayes v3.1.2 (Ronquist \& Huelsenbeck, 2003) was used to calculate marginal posterior probabilities using the GTR $+I+\Gamma$ model of nucleotide substitution for each partition. Model parameter values were treated as unknown and were estimated in each analysis. Random starting trees were used and analyses were run 1 million generations, sampling the Markov chain every 100 generations. The analysis was performed twice, in each case starting from a different random tree to ensure the analyses were not trapped in local optima. Stationarity was deemed to be reached when the average standard deviation of split frequencies, shown in MrBayes 3.1.2 was less than 0.01 (Ronquist \& Huelsenbeck, 2003).

The program Tracer v1.3 (Rambaut \& Drummond, 2003) was used to determine the correct "burn-in" for the analysis (i.e., the number of initial generations that must be discarded before stationarity is reached).

\section{RESULTS}

The 93 Benthoctopus specimens from the Antarctic Peninsula ranged in ML from 18-105 $\mathrm{mm}$. Size-frequency distribution was unimodal with the strong mode from 50-70 mm ML (Fig. 1). The relationship between $M L$ and total length was essentially linear (Fig. 2). Sex ratio was 1.6 , male dominant.
Molecular Analyses

Sequences generated in this study are available from GenBank under accession numbers FJ428003-FJ428015.

The sequences of the two Benthoctopus rigbyae $\mathrm{n}$. sp. individuals from stations $61 / 048-1$ and 42/003 on the Antarctic Peninsula (Fig 3 ) were identical $(P P=100, B S=98)$. These specimens form a monophyletic group with Benthoctopus sp. from station 39/014 in the Weddell Sea, which is highly supported by Bayesian posterior probabilities (PP) (PP = $100)$ and maximum likelihood bootstrap (BS) values $(B S=92)$. The sequences of Benthoctopus sp. from sta 39/014 in the eastern Weddell Sea (Fig. 1) differ from those of Benthoctopus rigbyae $\mathrm{n}$. sp. by $0.7 \%$ (4 base pairs) for the gene $16 \mathrm{~S}$ rDNA and $2.7 \%$ (18 base pairs) for the gene $\mathrm{COI}$.

The sequences of the two Benthoctopus levis individuals, captured from Heard Island, were almost identical (differing by only $0.15 \%$ ( 1 base pair) in the gene $\mathrm{COI}$ and $0.18 \%$ (1 base pair) in the gene 16S rDNA and grouped together in the tree $(P P=100, B S=100)$. Benthoctopus levis is the sister taxa to Benthoctopus thielei $(P P=62, B S=62)$ from Kerguelen Island. The clade containing Benthoctopus levis and Benthoctopus thielei forms a sister taxa relationship to the clade containing Benthoctopus rigbyae $\mathrm{n}$. $\mathrm{sp}$. and Benthoctopus $\mathrm{sp}$. from the eastern Weddell Sea. This relationship is not highly supported however. 


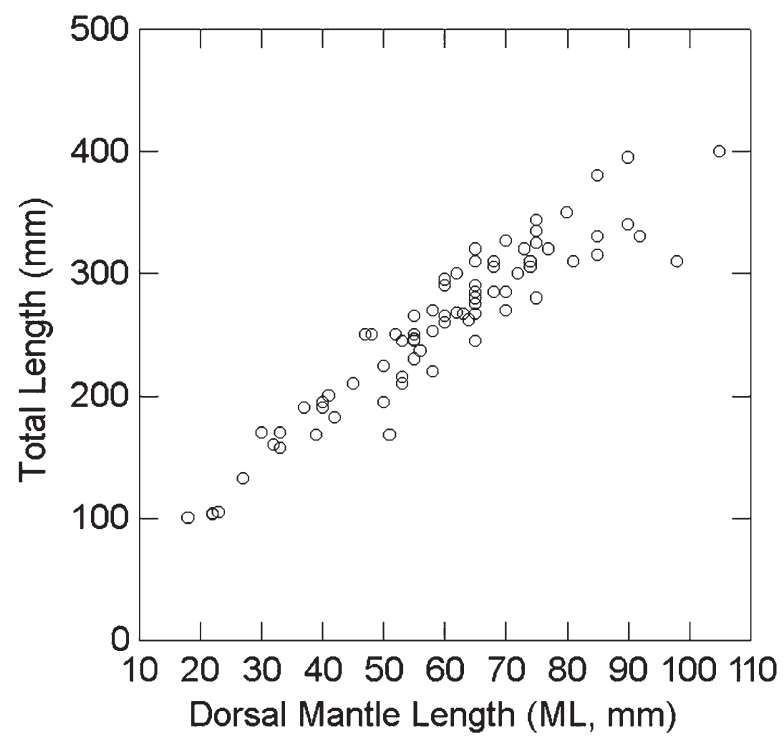

FIG. 2. Relationship between dorsal mantle length and total length of Benthoctopus rigbyae $\mathrm{n}$. $\mathrm{sp}$.

A sister taxa relationship is present between the clade containing Benthoctopus from the Southern Ocean (Benthoctopus rigbyae $\mathrm{n}$. sp., Benthoctopus sp. from the eastern Weddell Sea, B. levis and B. thielei) and B. johnsoniana. $(P P=98, B S=84)$. Benthoctopus normani is basal within the Benthoctopus species included in this phylogenetic study.

\section{Systematics}

Benthoctopus rigbyae, n. sp.

Holotype: Polarstern ANT XIV/2 sta. 42/022, mature male, 64 mm ML, USNM 1117765.

Paratypes: Polarstern ANT XIV/2 sta. 42/022, 2 mature females, 55 and $52 \mathrm{~mm} \mathrm{ML}$, USNM 1117766.

Other material examined: Polarstern ANT $\mathrm{XIV} / 2$ : Sta. 42/003, 2 immature males, 27 and $48 \mathrm{~mm}$ ML, 2 immature females, 24 and $30 \mathrm{~mm}$ ML, USNM 1021054; sta. 42/014, 1 immature male, $58 \mathrm{~mm} \mathrm{ML}$ and 1 mature female, $90 \mathrm{~mm}$ ML, USNM 1020987; sta. 42/017, 1 spent? female, $58 \mathrm{~mm} \mathrm{ML}$; sta. 42/020, 1 immature male, $39 \mathrm{~mm} \mathrm{ML;} \mathrm{sta.} \mathrm{42/021,} 1$ mature male, $74 \mathrm{~mm} \mathrm{ML}, 1$ immature male, $51 \mathrm{~mm} \mathrm{ML}, 1$ juvenile, $18 \mathrm{~mm} \mathrm{ML}$; sta. 42/022, 3 immature males, 22-37 mm ML; sta. 42/023, 1 male, mantle and viscera missing, USNM 1021986; sta. 42/029, 2 mature females, 47 and $81 \mathrm{~mm}$ ML, 1 male, mantle and viscera missing; sta. 42/036, 2 mature males, 73 and $85 \mathrm{~mm} \mathrm{ML,} 1$ mature female, $66 \mathrm{~mm} \mathrm{ML,} 1$ immature male, $45 \mathrm{~mm} \mathrm{ML}, 1$ immature female, $32 \mathrm{~mm} \mathrm{ML}$; sta. 42/040, 5 mature males, 65-75 mm ML, 3 mature females, 48-90 mm ML, 1 immature male, $40 \mathrm{~mm} \mathrm{ML}$; sta. 42/041, 1 mature male, $53 \mathrm{~mm}$. ML; sta. 42/043, 1 mature female, $65 \mathrm{~mm} \mathrm{ML;}$ sta. 42/047, 1 mature female, $50 \mathrm{~mm} \mathrm{ML}$; sta. 42/080, 1 mature male, $63 \mathrm{~mm}$ ML. Polarstern ANT XIX/3: Sta. 61/044-1, 1 mature female, 70 mm ML, NMSZ 2002037.030; sta. 61/045-1, 1 mature male, 98 mm ML, NMSZ 2002037.031; sta. $61 / 048-1,1$ immature male, $42 \mathrm{~mm} \mathrm{ML}$, NMSZ 2002037.032; sta. 61/049-1, 2 immature females, 70-75 mm ML, NMSZ 2002037.033; sta. $61 / 059-1,9$ mature males, $55-85 \mathrm{~mm}$. ML, 5 immature males, 40-65 mm ML, 2 mature females, each $55 \mathrm{~mm} \mathrm{ML}, 2$ immature females, 45-60 mm ML, 1 juvenile female, $30 \mathrm{~mm} \mathrm{ML}$, 5 specimens preserved, NMSZ 2002037.034; sta. 61/060-1, 1 immature female, $41 \mathrm{~mm}$. ML; sta. 61/062-1, 1 mature male, $65 \mathrm{~mm} \mathrm{ML;} \mathrm{sta.}$ 61/064-1, 3 mature males, 75-92 mm ML, 1 immature male, $62 \mathrm{~mm} \mathrm{ML}, 1$ juvenile male, 33 $\mathrm{mm} \mathrm{ML}, 3$ immature females, 56-68 mm ML; sta. 61/101-1, 1 immature male, $60 \mathrm{~mm} \mathrm{ML;}$ sta. 61/103-1, 2 mature males, 72-85 mm ML, 1 juvenile male, $27 \mathrm{~mm} \mathrm{ML}, 2$ mature females, 


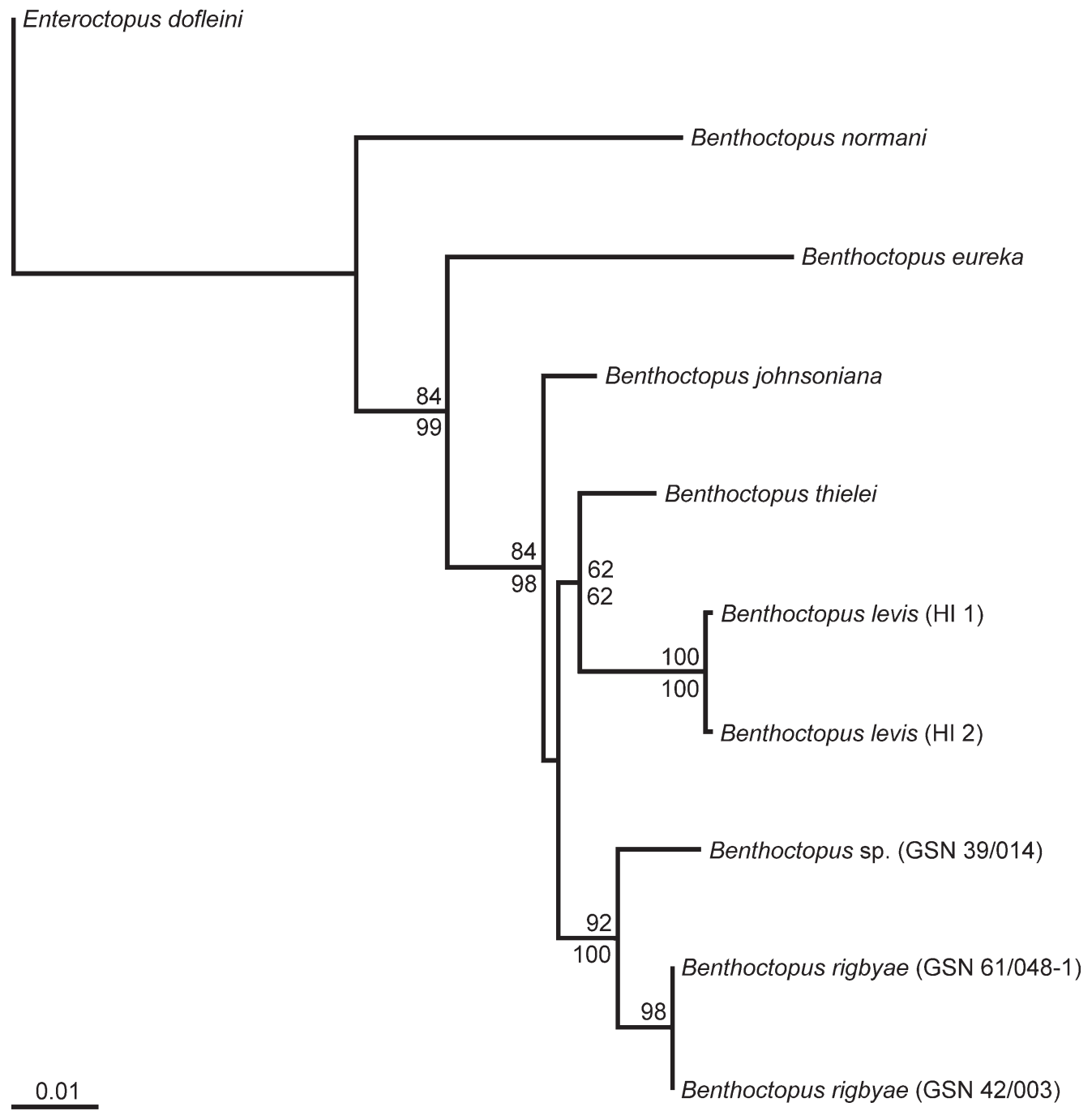

FIG. 3. Maximum likelihood tree depicting the phylogenetic relationship of seven species (ten individuals) of Octopoda. The analysis employed three mitochondrial sequences (12S rDNA, 16S rDNA, COI) concatenated. Bayesian support values are indicated below the nodes, maximum likelihood bootstrap values are indicated above the nodes.

80-105 mm ML, 1 immature female, $60 \mathrm{~mm}$ $\mathrm{ML}$; sta. 61/107-1, 1 juvenile male, $23 \mathrm{~mm} \mathrm{ML;}$ sta. 61/109-1, 1 mature female, $53 \mathrm{~mm} \mathrm{ML}, 1$ immature female, $53 \mathrm{~mm} \mathrm{ML;} \mathrm{sta.} \mathrm{61/111-1,}$ 1 juvenile male, $22 \mathrm{~mm}$ ML. Polarstern ANT XXIII/8: sta. 69/609-1, 1 juvenile, 24 mm ML; sta. 69/616-1, 1 immature female, $41 \mathrm{~mm} \mathrm{ML;}$ sta. 69/652-1, 1 immature female, $20 \mathrm{~mm} \mathrm{ML;}$ sta. 69/654-6, 1 immature female, $32 \mathrm{~mm} \mathrm{ML;}$ sta. 69/661-2, 1 immature female, $57 \mathrm{~mm} \mathrm{ML}$; sta. 69/662-1, 1 mature male, $61 \mathrm{~mm} \mathrm{ML;} \mathrm{sta.}$ 69/663-1, 1 immature female, $47 \mathrm{~mm} \mathrm{ML}$, sta. 69/664-1, 2 immature female, 34-49 mm ML.

Diagnosis

Antarctic octopod with biserial suckers and W-shaped funnel organ, lacking an ink sac. Arms long, 72-94\% of total length, with shallow webs approximately $20 \%$ of longest arm 
TABLE 4. Counts from specimens of Benthoctopus rigbyae n. sp. See Table 3 for abbreviations.

\begin{tabular}{lrrrrrrr}
\hline & min & median & mean & s.d. & c.v. & $\max$ & N \\
\hline Suckers on hectocotylized arm & 61 & 66 & 67 & 4 & 0.06 & 78 & 15 \\
Suckers on left ventrolateral arm & 113 & 148 & 144 & 14 & 0.1 & 165 & 25 \\
Suckers on longest arm & 124 & 146 & 144 & 11 & 0.08 & 164 & 24 \\
Inner gill lamellae & 5 & 7 & 7 & 0.7 & 0.12 & 8 & 27 \\
Outer gill lamellae & 6 & 6 & 7 & 0.6 & 0.1 & 8 & 27 \\
\hline
\end{tabular}

length. Hectocotylized arm with $60-80$ suckers, $56-75 \%$ length of longest arm. Ligula length $6-16 \%$ of hectocotylized arm length.

\section{Description}

Measurement, counts, and indices and their associated statistics are summarized in Tables $3-5$.

General Appearance of Live/Fresh Animal (Fig. 4): A moderately large octopod, to at least 105 mm ML, 400 mm TL. Chromatophores very tiny. Overall color light brownish orange, grading to lighter color ventrally and orally but darker at bases of suckers on some animals. Some animals showed a blotchy pattern on the mantle and web, but no changes in color pattern were noted during observation of live animals. Skin smooth, without papillae or superocular cirri. Mantle with obvious dorsal hump, no distinct lateral ridge or keel, although some animals exhibited a band of raised skin laterally on mantle. Arms long. Web formula variable; web shallow, extends along ventral arm to tip and along dorsal arm, attaching to aboral arm surface approximately 1/3-1/2 arm length from proximal. Eyes prominent, dark, with bluish sheen. Mantle muscular.

External Morphology (Fig. 5): Head narrower (approximately 67\%) than mantle, head width about $63 \%$ ML. Mantle width only slightly less than ML. Arms often regenerating but very long,

TABLE 5. Indices from specimens of Benthoctopus rigbyae n. sp. See Table 3 for abbreviations.

\begin{tabular}{lccccccc}
\hline & min & median & mean & s.d. & c.v. & max & N \\
\hline Dorsal mantle length / Total length & 0.18 & 0.23 & 0.23 & 0.03 & 0.11 & 0.32 & 78 \\
Ventral mantle length / Dorsal mantle length & 0.77 & 0.91 & 0.91 & 0.08 & 0.08 & 1.05 & 27 \\
Mantle width / Dorsal mantle length & 0.72 & 0.93 & 0.93 & 0.09 & 0.09 & 1.15 & 27 \\
Head width / Dorsal mantle length & 0.46 & 0.61 & 0.62 & 0.08 & 0.13 & 0.79 & 27 \\
Head width / Mantle width & 0.53 & 0.64 & 0.67 & 0.08 & 0.12 & 0.84 & 27 \\
Eye diameter / Dorsal mantle length & 0.22 & 0.29 & 0.30 & 0.04 & 0.14 & 0.38 & 27 \\
Full funnel length / Dorsal mantle length & 0.36 & 0.44 & 0.43 & 0.05 & 0.12 & 0.54 & 27 \\
Free funnel length / Dorsal mantle length & 0.21 & 0.31 & 0.30 & 0.05 & 0.15 & 0.41 & 27 \\
Deepest web depth / Dorsal mantle length & 0.41 & 0.71 & 0.72 & 0.15 & 0.20 & 0.98 & 23 \\
Deepest web depth / Longest arm length & 0.09 & 0.18 & 0.19 & 0.03 & 0.18 & 0.25 & 24 \\
Calamus length / Dorsal mantle length & 0.09 & 0.12 & 0.13 & 0.02 & 0.14 & 0.15 & 14 \\
Calamus length / Hectocotylized arm length & 0.03 & 0.05 & 0.05 & 0.01 & 0.24 & 0.08 & 15 \\
Ligula length / Dorsal mantle length & 0.18 & 0.27 & 0.26 & 0.03 & 0.13 & 0.30 & 14 \\
Ligula length / Hectocotylized arm length & 0.06 & 0.10 & 0.11 & 0.03 & 0.25 & 0.16 & 15 \\
Longest arm length / Dorsal mantle length & 2.50 & 3.77 & 3.75 & 0.63 & 0.17 & 4.89 & 27 \\
Longest arm length / Total length & 0.72 & 0.83 & 0.83 & 0.07 & 0.08 & 0.94 & 25 \\
Hectocotylized arm length/Opposite arm length & 0.56 & 0.76 & 0.74 & 0.09 & 0.12 & 0.90 & 15 \\
\hline
\end{tabular}




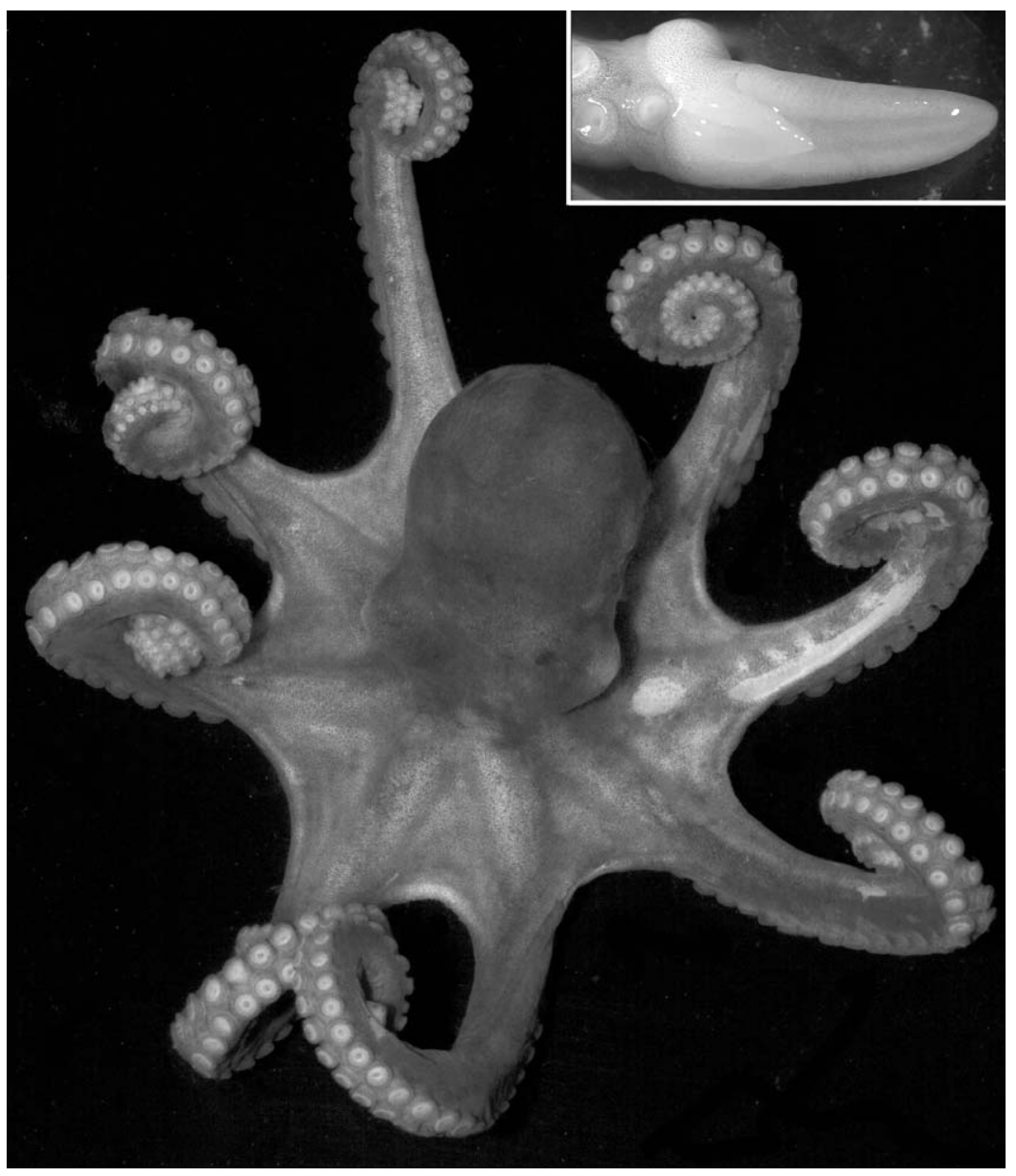

FIG. 4. Shipboard photograph of a live animal of Benthoctopus rigbyae $n$. sp. (by E. Jorgensen, 2007). Note nearly uniform color, lack of papillae and lack of skin components. Inset: Close-up of the hectocotylized arm tip of a mature male.

comprising $70-90 \%$ of total length, generally 3-4 times ML. Order of arm length variable but non-hectocotylized arms typically subequal in length, with 113-165 suckers. Variability in sucker counts partly a result of difficulty in counting very many pairs of miniscule suckers on arm tips. Hectocotylized right ventrolateral arm (Fig. 6a) length approximately $75 \%$ of opposite arm length. Sucker number on hectocotylized arm 61-78. Suckers small, maximum diameter 1-3\% of arm length or approximately $7.5 \% \mathrm{ML}$. Sucker series widely separated, with zigzag pattern of transverse ridges and grooves between adjacent suckers (Fig. 6a). Distinctly enlarged suckers absent. Ligula with indistinct median ridge and numerous faint transverse creases that sometimes are barely visible. Ligula length approximately $10 \%(6-16 \%)$ of hectocotylized arm length or $26 \%$ (18-30\%) of ML. Calamus sharply pointed, length approximately half $(0.46-0.50 \%)$ of ligula length. Funnel length approximatrely $1 / 3-1 / 2 \mathrm{ML}$; length of free funnel approximately $20-40 \% \mathrm{ML}$.

Internal Anatomy: Funnel organ W-shaped, with moderately thick limbs. Chromatophores present in lining of buccal cavity. Beaks as in Figure 6e-g. Radula (Fig. 6j): rachidian multicuspid, 2 pairs laterals small and triangular, $2^{\text {nd }}$ larger than $1^{\text {st }}, 1$ pair marginal teeth curved 


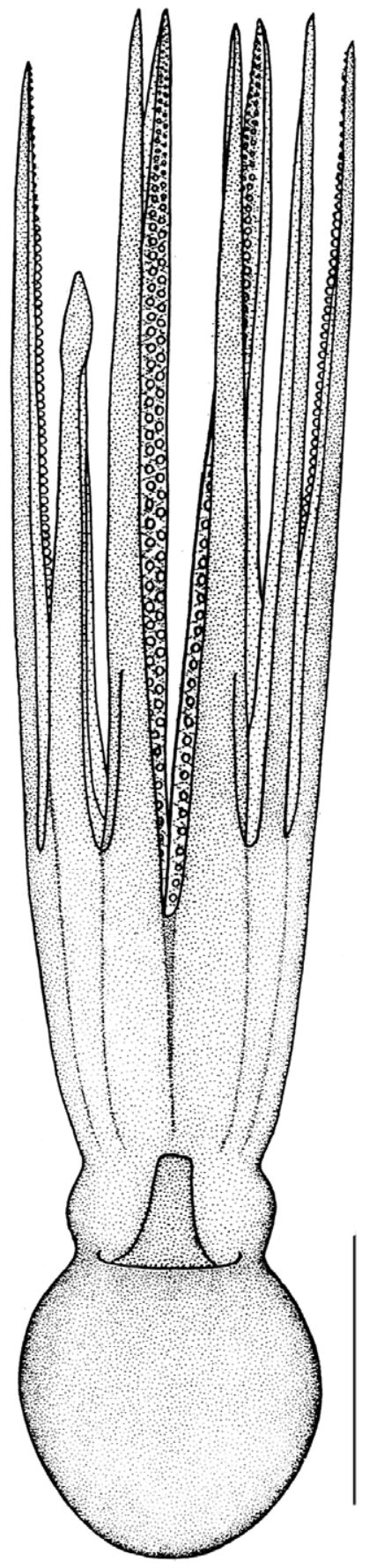

FIG. 5. Benthoctopus rigbyae n. sp. external anatomy, ventral view, male, $70 \mathrm{~mm}$ ML. Scale bar $=50 \mathrm{~mm}$. and much larger than laterals, 1 pair marginal plates. Dorsal visceral membrane densely covered with chromatophores. Digestive gland (Fig. 6h, i) almost spherical but slightly flattened dorso-ventrally, with shallow depression for esophagus, stomach and caecum, cream to deep maroon in color. Esophagus straight, slightly expanded in crop region, no crop diverticulum. One octopod when dissected had ventral area of crop region swollen and spherical with fluid. Anterior salivary glands large, dorsolateral on buccal mass. Posterior salivary glands moderately large, each similar in size to stomach. Stomach and caecum about equal in size. Intestine straight. Male reproductive tract as illustrated in Figure 6c, d. Accessory spermatophore gland longer than Needham's sac. An $80 \mathrm{~mm}$ ML male had 28 mature spermatophores in Needham's sac; one of $63 \mathrm{~mm}$ $\mathrm{ML}$ had 24, with lengths ranging from 55 to $102 \mathrm{~mm}$ (mean $94 \mathrm{~mm}$ ). Female reproductive tract as illustrated in Figure $6 \mathrm{~b}$. Oviducts narrow, exit from antero-ventral membrane of ovary separately but contiguously, then bend laterally and funnel into round oviducal glands. In mature females, distal oviducts longer than proximal, white and thick, diameter only slightly less than that of oviducal gland. Mature ovarian eggs elongate, 13-24 mm long (mean $17 \mathrm{~mm}$ ) x 3-8 mm wide (mean $6 \mathrm{~mm}$ ). An $81 \mathrm{~mm}$. ML female had 88 mature and 4 immature $(3 \times 8$ to $3 \times 10 \mathrm{~mm}$ ) eggs in ovary.

Size at Maturity: Maturity of males increases gradually with increasing size (Fig. 7). Females, on the other hand, exhibit a wide range of maturity stages over a fairly narrow size range (Fig. 8). This may indicate that although most females appear to attain larger sizes than males, females mature rapidly once a threshold size has been reached.

Stomach Contents: Of 15 stomachs opened ( $n=9$ females, 6 males), eight were empty ( $n$ = 6 females, 2 males) and seven were partly filled but not distended ( $n=3$ females, 4 males). Two stomachs contained only amphipod remains; one contained amphipod and fish remains in approximately equal volumes; one contained half amphipod remains together with the remains of serolid isopods, polychaetes, bryozoans and sponge spicules. One stomach contained solely the remains of ophuroids. Two stomachs contained unidentifiable crustacean remains. 
NEW ANTARCTIC BENTHOCTOPUS

23

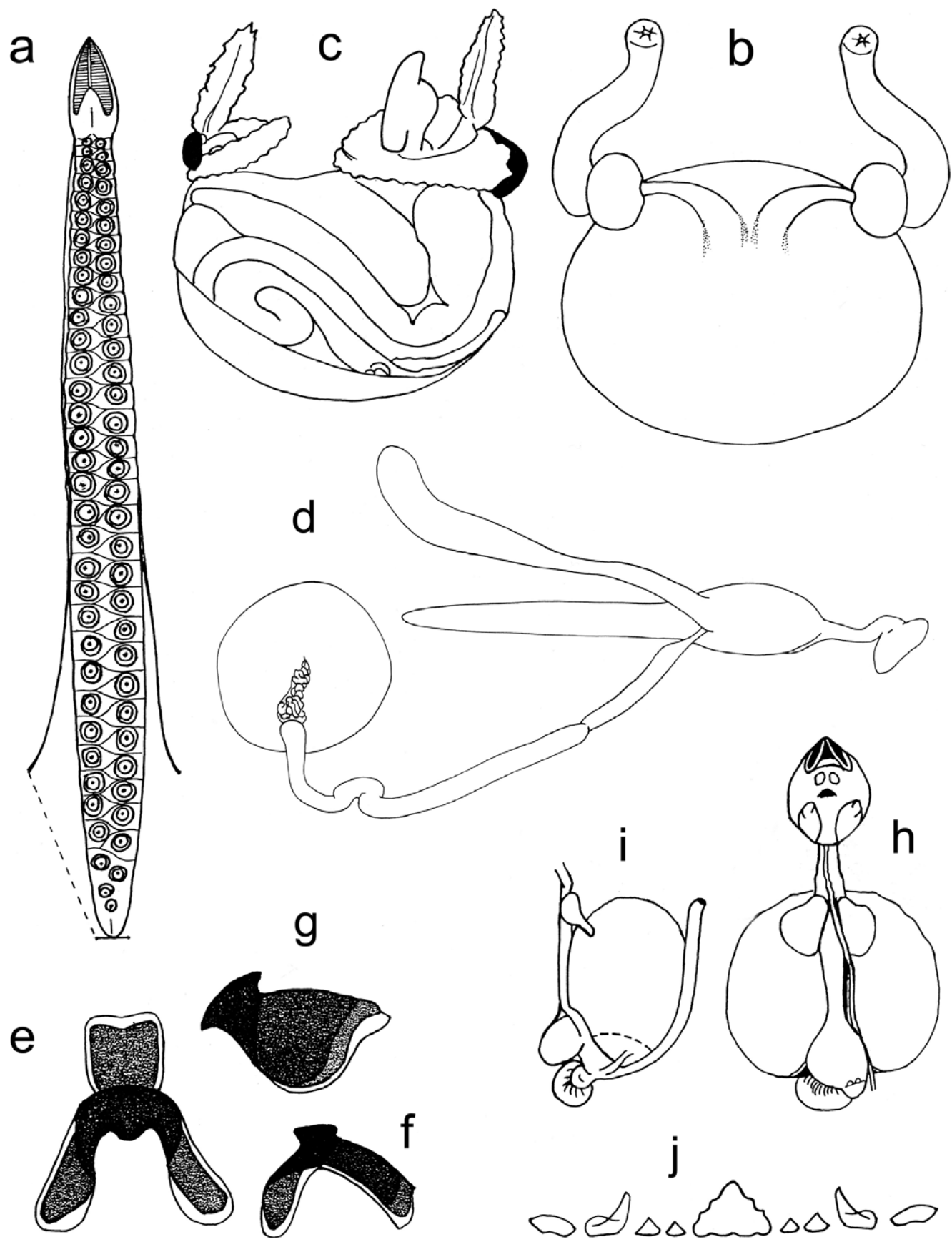

FIG. 6. Benthoctopus rigbyae n. sp. Internal anatomy (a) hectocotylized arm, (b) female reproductive system, (c) male reproductive system as seen in the viscera, (d) male reproductive system dissected to show structure, (e) lower beak, ventral view, (f) lower beak, lateral view, $(\mathrm{g})$ upper beak, lateral view, (h) digestive system, dorsal view, (i) digestive system, lateral view, (j) one row of radular teeth. 


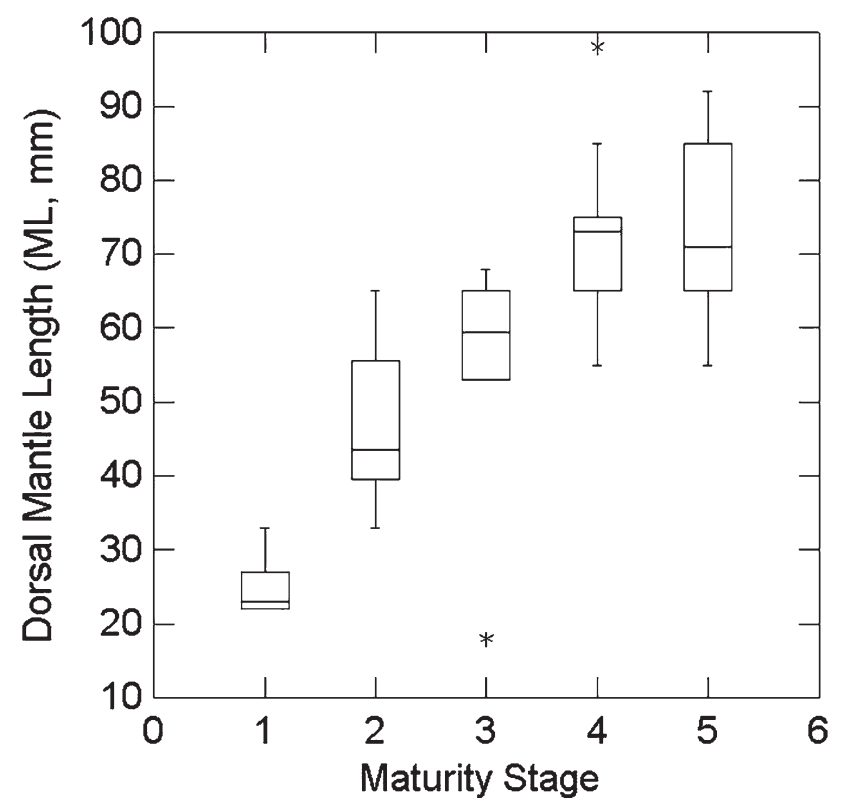

FIG. 7. Relationship between maturity stage and dorsal mantle length for male Benthoctopus rigbyae $\mathrm{n}$. $\mathrm{sp}$.

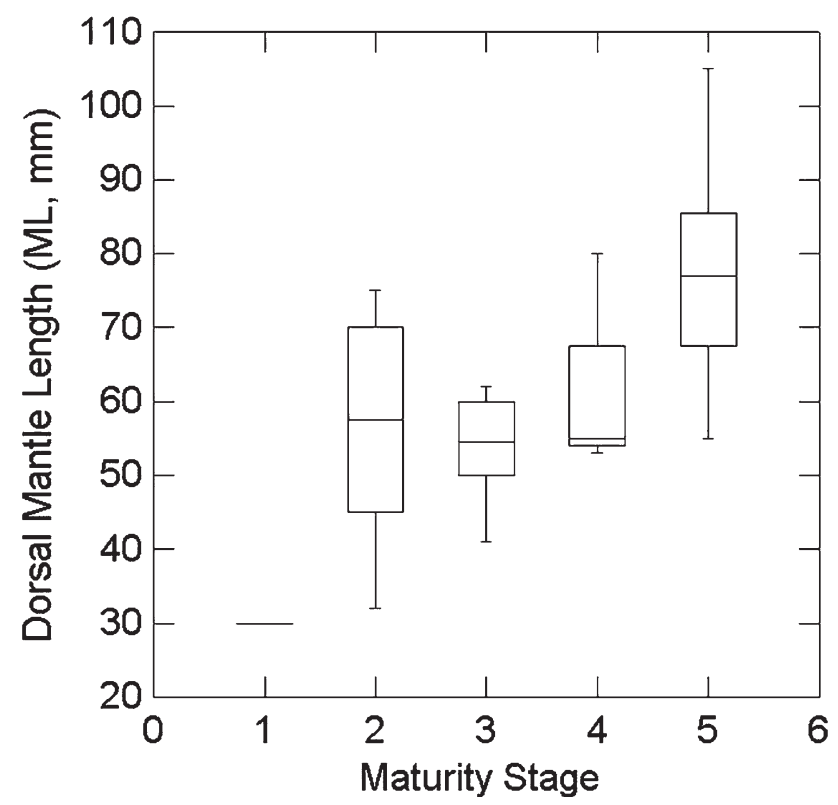

FIG. 8. Relationship between maturity stage and dorsal mantle length for female Benthoctopus rigbyae n. sp. 

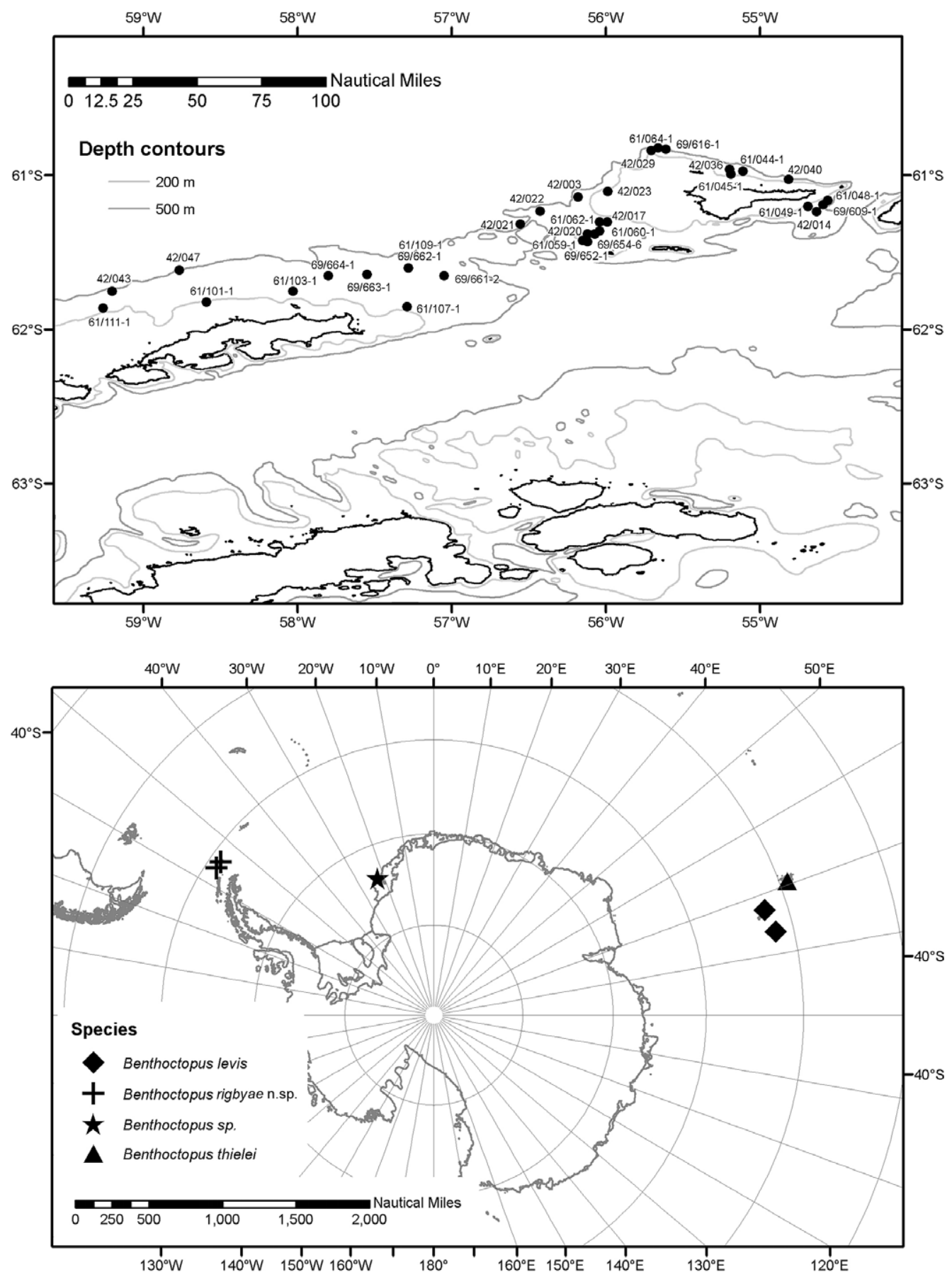

FIG. 9. Distribution of Benthoctopus rigbyae $\mathrm{n}$. sp. catches in the vicinity of the South Shetland Islands (top); Distribution of Benthoctopus spp. around Antarctica (bottom). 
Length/Weight Relationship: The relationship between total length and weight, including all maturity stages, was similar between the sexes. For females the relationship could be described by the power function $y=0.0492 x^{1.9845}, r^{2}=$ 0.8984 . The function descriptive of the males is $y=0.0023 x^{2.6887}, r^{2}=0.9298$

\section{Distribution}

These octopods were common, though not abundant, along the outer shelf and upper slope of entire South Shetland Island chain, depth range 250-600 $\mathrm{m}$ (Fig. 9). They comprised $<2 \%$ of the octopod fauna sampled. The maximum number collected in a 30-min tow with the bottom trawl was 18.

\section{DISCUSSION}

Octopods with biserial suckers but lacking an ink sac currently are considered to belong to either Bathypolypus or Benthoctopus. The former is fairly well defined (Muus, 2002), based primarily on morphology of the hectocotylus, which has a very large ligula characterized by prominent transverse laminae. Although the males described here have fairly large ligulae with very faint transverse creases, their long arms, small suckers, and smooth skin make them more similar to Benthoctopus than Bathypolypus. Benthoctopus, however, has tended to be a "catch-all" taxon including any such octopod that does not clearly belong to Bathypolypus. The genus as currently defined probably is not holophyletic. Species of the genus Benthoctopus described from the area of the Antarctic Polar Frontal Zone (APFZ) or further south include just $B$. theilei Robson, 1932, and $B$. levis (Hoyle 1885). The type localities of $B$. theilei and $B$. levis lie on the APFZ off the Kerguelen Islands and south of the APFZ off Heard Island respectively.

Based on published descriptions, the specimens described here are most similar to $B$. levis. However, they differ in relative arm length, web depth, lengths of the hectocotylized arm and ligula. One of us (L.A.) examined the holotype of $B$. levis (BMNH 1889.4.24.43) and found that its funnel organ is VV-shaped rather than $W$-shaped. A photograph of $B$. levis from near the type locality published by Norman (2000) shows an octopod similar to ours, but with shorter arms and a deeper web. Benthoctopus rigbyae is easily distinguished from $B$. thielei as the latter has a VV funnel organ (illustrated by Robson, 1932: 234).

Although similar to $B$. levis, the specimens we describe differ sufficiently in morphology for us to believe they represent a separate species. This conclusion is supported by the molecular data. Benthoctopus rigbyae $\mathrm{n} . \mathrm{sp}$. is the sister taxon to Benthoctopus sp. from the eastern Weddell Sea, whilst $B$. levis is the sister taxon to $B$. thielei. The Weddell Sea specimen differs from $\boldsymbol{B}$. rigbyae by 18 base pairs in $\mathrm{COI}$ the DNA bar-coding gene. We must therefore conclude that the Weddell Sea specimen also represents a different, currently undescribed species. Measurements taken shortly after capture support this. However, this specimen was destroyed due to mechanical failure of a freezer prior to fixation and is no longer extant.

To discover two species in the western Southern Ocean is not surprising given that these Benthoctopus species appear to inhabit shallower waters than they do elsewhere. Benthoctopus rigbyae is known from $200-600 \mathrm{~m}$ and the Weddell Sea specimen was captured at $850 \mathrm{~m}$. Between the South Shetland Islands and the eastern Weddell Sea, water depths exceed the maximum known depth for the species. Given that mature ovarian eggs of $\boldsymbol{B}$. rigbyae have been recorded at $24 \mathrm{~mm}$ length and undoubtedly hatch into benthic crawl-away young, opportunities for gene flow between the Peninsula region and the eastern Weddell Sea would be extremely limited. Thus, there is limited possibility of a continuous population around the Antarctic continent because of the FilchnerRonne Ice Shelf which extends out over water depths greater than $1,000 \mathrm{~m}$.

It is perhaps more surprising to find clearly differentiated species between the Kerguelen Islands and Heard Island. The geographic distance between these islands is small and both are situated on the Kerguelen plateau meaning that there is no deep water trench between them. It is possible that the APFZ in this region is influential in delimiting two distinct microhabitats.

\section{Etymology}

Named in memory of Robin Rigby, a bright, young cephalopod biologist.

\section{ACKNOWLEDGMENTS}

We thank the Alfred Wegener Institute for Polar and Marine Research (AWI), the Captain 
and crew of R/V Polarstern, and Karl-Hermann Kock for facilitating our field work. Silke Steimer, Martin Hevia Werkmeister, Markus Seemen, lain Barratt, and Elaina Jorgensen all assisted with the field work. Elaina also provided the photograph of the live octopod. Kirrily Moore provided the Benthoctopus levis and Yves Cherel gave us the beak from $B$. thielei. JS was supported by a Natural Environment Research Council Antarctic Funding Initiative grant (NE/ C506321/1) awarded to LA.

\section{LITERATURE CITED}

ALLCOCK, A. L., 2005, On the confusion surrounding Pareledone charcoti: endemic radiation in the Southern Ocean. Zoological Journal of the Linnean Society, 143: 75-108.

ALLCOCK, A. L., U. PIATKOWSKI, P. K. G. RODHOUSE \& J. P. THORPE, 2001, A study on octopodids from the eastern Weddell Sea, Antarctica. Polar Biology, 24: 832-838.

ALLCOCK, A. L., J. M. STRUGNELL, H. RUGGIERO \& M. A. COLLINS, 2006, Redescription of the deep-sea octopod Benthoctopus normani (Massy 1907) and a description of a new species from the Northeast Atlantic. Marine Biology Research, 2: 372-387.

ARNTZ, W. E. \& T. BREY, eds., 2001, The expedition ANTARKTIS XVII/3 (EASIZ III) of R.V. Polarstern in 2000. Berichte zur Polar- und Meeresforschung, 402: 1-181.

BARRATT, I. \& E. JORGENSEN, 2008, Cephalopod diversity and ecology. Berichte zur Polarund Meeresforschung, 569: 120-126.

DALY, H.I. \& P. G. K. RODHOUSE, 1994, Comparative morphology of two sympatric Pareledone species from South Georgia. Antarctic Science, 6: 163-170.

DELL, R. K., 1972, Antarctic benthos. Advances in Marine Biology, 10: 1-216.

FOLMER, O., M. BLACK, W. HOEH, R. LUTZ \& R.VRIJENHOEK, 1994, DNA primers for amplification of mitochondrial cytochrome c oxidase subunit from diverse metazoan invertebrates. Molecular Marine Biology and Biotechnology, 3: 294-299.

HOYLE, W. E., 1885, Diagnoses of new species of Cephalopoda collected during the cruise of H.M.S. Challenger, I: The Octopoda. Annals and Magazine of Natural History, (ser. 5) 15: 222-236

KATTNER, G., ed., 1998, The expedition ANTARKTIS XIV/2 of R.V. Polarstern in 1996/7. Berichte zur Polarforschung, 274: 1-87.

KUEHL, S., 1988, A contribution to the reproductive biology and geographical distribution of Antarctic Octopodidae (Cephalopoda). Malacologia, 29: 89-100.

KUBODERA, T. \& T. OKUTANI, 1994, Eledonine octopods from the Southern Ocean: systematics and distribution. Antarctic Science, 6: 205-214.
LU, C. C. \& T. N. STRANKS, 1994, Synopsis of Pareledone and Megaleledone species, with description of two new species from east Antarctica (Cephalopoda: Octopodidae). Memoirs of the National Museum of Victoria, 54: 221-242.

MASSY, A. L., 1907, Preliminary Notice of New and Remarkable Cephalopods from the Southwest Coast of Ireland. Annals and Magazine of Natural History, (7) 20: 377-384.

MUUS, B., 2002, The Bathypolypus-Benthoctopus problem of the North Atlantic (Octopodidae, Cephalopoda). Malacologia, 44: 175-222.

NORMAN, M., 2000, Cephalopods, a world guide. ConchBooks, Hackenheim. 318 pp.

PIATKOWSKI, U., L. ALLCOCK, M. HEVIA, S STEIMER \& M. VECCHIONE, 1998, Cephalopod ecology. Berichte zur Polarforschung, 274 41-47.

PIATKOWSKI, U., A. L. ALLCOCK \& M. VECCHIONE, 2003, Cephalopod diversity and ecology. Berichte zur Polar- und Meeresforschung, 470: 32-38.

RAMBAUT, A., 2002, Se-Al. Ver. v2.0a11 Carbon. Oxford University.

RAMBAUT, A. \& A. J. DRUMMOND, 2003, Tracer 1.0.1. Oxford University.

ROBSON, G. C., 1932, A monograph of the recent Cephalopoda. Part II. The Octopoda (excluding the Octopodinae). British Museum (Natural History), London. 359 pp.

RONQUIST, F. \& J. P. HUELSENBECK, 2003, MrBayes 3: Bayesian phylogenetic inference under mixed models. Bioinformatics, 19: 1572-1574.

ROPER, C. F. E. \& G. L. VOSS, 1983, Guidelines for taxonomic descriptions of cephalopod species. Memoirs of the National Museum of Victoria, 44: 49-63.

SAITOU, N. \& M. NEI, 1987, The neighbor-joining method. a new method for reconstructing phylogenetic trees. Molecular Biology and Evolution, 4: 406-425.

SIMON, C., S. PÄÄBO, T. KOCHER \& A. C. WILSON, 1990, Evolution of the mitochondrial ribosomal RNA in insects as shown by the polymerase chain reaction. Pp. 142-180, in: M. T. CLEGG \& S. J. O'BRIAN, eds., Molecular evolution, UCLA symposia on molecular and cellular biology, (n.s.) 122. Wiley, New York. xviii $+322 \mathrm{pp}$.

SIMON, C., A. FRANKE \& A. P. MARTIN, 1991 The polymerase chain reaction: DNA extraction and amplification. Pp. 329-355, in: G. M. HEWITT, A. W. B. JOHNSTON \& J. P. W. YOUNG, eds., Molecular techniques in taxonomy. NATO Advanced Studies Institute, H57. Springer, Berlin. $\mathrm{X}+407 \mathrm{pp}$

STRUGNELL, J., M. NORMAN, A. J. DRUMMOND, J. JACKSON \& A. COOPER, 2005 Molecular phylogeny of coleoid cephalopods (Mollusca: Cephalopoda) using a multigene approach; the effect of data partitioning on resolving phylogenies in a Bayesian framework. Molecular Phylogenetics and Evolution, 37: 426-441.

STRUGNELL, J., M. NORMAN \& A. COOPER, 2006, DNA from beach-washed shells of the 
Ram's Horn squid (Spirula spirula) (Linnaeus 1758) Bulletin of Marine Science, 78(2): 389-391.

SWOFFORD, D. L., 1998, PAUP*4.0-Phylogenetic Analysis Using Parsimony (*and Other Methods). Sinauer, Sunderland, Massachusetts.

TAKI, I., 1961, On two new eledonid octopods from the Antarctic sea. Journal of the Faculty of Fish and Animal Husbandry, Hiroshima University, 3: 297-316, pls. 1-3.

WÜLKER, G., 1910, Über Japanische Cephalopoden: Beiträge zur kenntnis der Systematik und Anatomie der Dibranchiaten. Abhandlungen der Mathematisch-Physikalischen Classe der Königlich Bayerischen Akademie der Wissenschaften, Supplement 1, 3: 1-77.

Revised ms. accepted 4 August 2008 